\title{
Genome evaluation of banana cultivars based on morphological character and Inter-Simple Sequence Repeat (ISSR) molecular marker
}

\author{
DIDIK WAHYUDI ${ }^{1, \bullet}$, KHAFIDHOTUR RIFLIYAH ${ }^{1}$, USLAN $^{2}$ \\ ${ }^{1}$ Department of Biology, Faculty of Science and Technology, Universitas Islam Negeri Maulana Malik Ibrahim Malang. Jl. Gajayana No. 50, Malang \\ 65144, East Java, Indonesia. Tel.lfax.: +62-341-558933. ”email: didik_wahyudi@bio.uin-malang.ac.id \\ ${ }^{2}$ Department of Biology Education, Faculty of Teacher Training and Education, Universitas Muhammadiyah Kupang. J1. KH. Ahmad Dahlan No. 17, \\ Kupang 85111, East Nusa Tenggara, Indonesia
}

Manuscript received: 13 April 2020. Revision accepted: 10 June 2020

\begin{abstract}
Wahyudi D, Rifliyah K, Uslan. 2020. Genome evaluation of banana cultivars based on morphological character and InterSimple Sequence Repeat (ISSR) molecular marker. Biodiversitas 21: 2982-2990. This study aims to evaluate the genome group and to investigate the genetic variability of banana cultivar using morphological character and ISSR molecular marker. Fourteen banana cultivars with genomic group AA, AAA, AAB, ABB, and BB was used. All samples were Identified morphologically based on minimal descriptors for bananas issued by the International Plant Genetic Resources Institute (IPGRI). Total genomic DNA was extracted using DNA Isolation Kit Promega Wizard®. ISSR primer was used in this study, including UBC834, UBC835, UBC843, UBC848, and UBC855. Clustering analysis was used to evaluate genome grouping of the banana cultivar. Clustering analysis of morphological character was performed using the unweighted pair group method with arithmetic mean (UPGMA) algorithm and Bray-Curtis coefficient similarity using Paleontological Statistics (PAST) software. Morphological and ISSR was successfully differentiate banana cultivars and relatively similar to previous genome grouping. However, pisang Triolin (AAB) must be evaluated since it belongs to AAA group. The identification of cultivars and classification of their genome groups based on morphological characteristics and proved by molecular markers will strengthen the establishment of Musa improvement strategy especially in Indonesia and ease the breeder to identify desirable traits of progenitor to be included in the breeding program.
\end{abstract}

Keywords: Banana cultivars, ISSR, genomic group, morphological character

\section{INTRODUCTION}

Banana and plantain are the most crucial commodity both for staple food and export commodity (Kharadi et al. 2014) especially in southeast Asia which is considered as a primary center origin of banana (Simmonds and Shepherd 1955; Perrier 2011). Numerous banana cultivars are recognized in Southeast Asia, mainly in Indonesia. More than 200 banana cultivars were well identified and cultivated throughout the Indonesian archipelago (Valmayor et al. 2000).

Bananas and plantains belong to the family Musaceae and Genus Musa, which are closely related to Musella and Ensete (Hapsari 2014). The term of banana and plantain was firstly specified by Karl Linneaus in 1753 and 1759 (Valmayor et al. 2000). The banana includes the dessert type that ready to be eaten fresh upon ripening. This kind of banana was named Musa sapientum as published in the famous Linnaeus book "Systema Naturae" in 1759. Another type of banana was plantain which is characterized as remain starchy while ripening and needed to be cooked before consumption. Then, Linnaeus gave scientific terms to the plantain as $M$. paradisiaca Linn as published in his book "Species Plantarum" in 1753 (Valmayor et al. 2000).

The description of banana and plantain by Linnaeus only closely fit with banana and plantain found in Latin America and West Africa and the two scientific names above still used almost two centuries. However, their application in Southeast Asia as center origin of banana generated confusion (Valmayor et al. 2000). In the center origin of bananas, especially in Indonesia, many banana cultivars are consumed either fresh and cooked, starchy, and dehiscent male flower and bracts (Hapsari and Lestari 2016). This banana was different from plantain description and cannot be classified under $M$. paradisiaca. Furthermore, the diversity of dessert bananas was also found in terms of plant stature and color that exceed with description of $M$. sapientum.

The majority of banana cultivars in Southeast Asia were sterile and originated from two wild progenitor $M$. acuminata and $M$. balbisiana which are endemic to Southeast Asia (Valmayor et al. 2000) and donating A and B Genome (Helshop-Harrison and Schwarzacher 2007). Inter and intraspecific crossbreeding between them generated sterile, seedless, and triploid banana cultivars. Since the sterility and total ploidy did not alter the morphological characteristic, the scientific name of $M$. acuminata and M. balbisiana should be applied for cultivar banana derived from them. This fact emerged the new classification scheme for banana cultivar in Southeast Asia in the term of coping the taxonomical confusion for banana cultivars. The tree tier system, including species, genome group, and cultivars was adopted specially for banana cultivars in Southeast Asia (Valmayor et al. 2000).

The taxonomic scorecard designed by Simmond and Shepherd (1959) was used to separate the genome of 
banana cultivars. The scorecard was developed by using 15 characters of vegetative and generative such as pseudo stem color, bract shape, peduncle, male flower, etc. However, genome determination by using morphological character was subjective and generated different results between researchers (Gusmiati et al. 2018; Probojati et al. 2019). Therefore, the molecular approach is needed to create a valid result. Some molecular methods are often used for gaining insight into individual genetic characteristic including Restriction Fragment Length Polymorphism (RFLP) (Hapsari et al. 2015), Random Amplified Polymorphic DNA (RAPD) (Sundari et al. 2017; Probojati et al. 2019), Variable Number Tandem Repeats (VNTR) (Garcia et al. 2011), Sequence-Related Amplified Polymorphism (SRAP) (Youseef et al. 2011; Valdez-Ojeda et al. 2014), Inter Simple Sequence Repeats (ISSR) (Kharadi et al. 2014; Poerba and Ahmad 2010) and sequencing (Wahyudi et al. 2015; Nikmah et al. 2016). However, ISSR is a reliable marker compared to others (Poerba and Ahmad 2010; Das et al. 2018).

ISSR is proven to produce more polymorphism data than RAPD (Poerba et al. 2018). Furthermore, ISSR is widely used for assessing genetic diversity and genome clustering of bananas (Das et al. 2018; Babu et al. 2018). However, no study has been found on the use of ISSR for genome detection of banana cultivar, especially in Indonesia. Therefore, this study aims to evaluate the genome group and to investigate the genetic variability of banana cultivar using morphological character and ISSR marker. This research is not only necessary in the taxonomy study but also as basic information on selective breeding and conservation.

\section{MATERIALS AND METHODS}

\section{Sample collection}

Three accessions of every genome group (except genome group BB with two accessions) of bananas were used. Total of fourteen banana cultivars with genomic group AA, AAA, AAB, ABB, and BB were collected. All sample was collected from Banana Germplasm Garden,
Yogyakarta Department of Agriculture, Indonesia. Genomic group of bananas was obtained from the collection book of banana cultivar of Banana Germplasm Garden, Yogyakarta Department of Agriculture, Indonesia, and cross-checked with the research of Hapsari et al. (2016). Young leaves (furled) of 14 banana cultivars were collected for DNA extraction.

\section{Morphological characterization}

All samples were Identified morphologically based on minimal descriptor for bananas (IPGRI, 1996), and crosschecked with information from the curators, also from some banana morphological references (Hapsari et al. 2016).

\section{DNA extraction and evaluation}

Fresh young leaves of banana were harvested and powdered in Liquid Nitrogen using mortar and pestle. Total genomic DNA was extracted using the DNA Isolation Kit Promega Wizard®. Steps of DNA isolation follow the guide instruction of Promega Wizard®. Evaluation of DNA extraction was performed qualitatively and quantitatively. DNA quality was evaluated by electrophoresis on $1 \%$ agarose gel, whereas DNA quantity was determined by AE-Nanodrop 200 Nucleic Acid.

\section{PCR analysis}

Five selected primers that proven to produce amplicon from previous research were used to assess genetic diversity and genome clustering (Table 1). PCR reaction was carried out in total volume $10 \mu \mathrm{l}$ containing $1 \mu \mathrm{l}$ of the sample $(25 \mathrm{ng}), 1 \mu \mathrm{l}$ of primer $(10 \mathrm{pmol}), 3 \mu \mathrm{l}$ nucleasefree water and $5 \mu \mathrm{l}$ DreamTaq DNA polymerase $(2 \mathrm{x}$ DreamTaq Green Buffer; 0,4 mM dNTPs dan mM MgCl2). The amplification was performed using PCR Biorad with one cycle of denaturation at $94{ }^{\circ} \mathrm{C}$ for $5 \mathrm{~min}$, followed by 35 cycles of denaturation at $94{ }^{\circ} \mathrm{C}$ for $4 \mathrm{sec}$, annealing at temperature annealing of each primer (Table 1) for $1 \mathrm{~min}$ and followed by extension at $72{ }^{\circ} \mathrm{C}$ for $1.5 \mathrm{~min}$. The amplification was ended by 1 cycle of final extension at 72 ${ }^{\circ} \mathrm{C}$ for $7 \mathrm{~min}$.

Table 1. Banana cultivars used in this study

\begin{tabular}{lll}
\hline Cultivar group & Cultivars name & Origin \\
\hline AA & Rejang & Sleman, Yogyakarta \\
& Mas & KBH, Dongkelan, Yogyakarta \\
AAA & Berlin & Banyuwangi, East Java \\
& Kojo Santen & Cukur Gondang, Pasuruan, East Java \\
& Ambon Hong & Purworejo, Central Java \\
AAB & Morosebo & Kotagede, Yogyakarta \\
& Raja Seribu & DKI Jakarta \\
ABB & Triolin & Bantul, Central Java \\
& Brentel Warangan & Karanganyar, Central Java \\
& Sobo Awu & Malang, East Java \\
BB & Ebung & Ponorogo, East Java \\
& Raja Bandung & Bantul, Central Java \\
\hline
\end{tabular}


Table 1. List of ISSR primers used in this

\begin{tabular}{clcc}
\hline $\begin{array}{c}\text { Primer } \\
\text { code }\end{array}$ & $\begin{array}{c}\text { The primer nucleotide sequence } \\
\left(\mathbf{5}^{\prime}-\mathbf{3}^{\prime}\right)\end{array}$ & $\begin{array}{c}\text { MT } \\
\left({ }^{\circ} \mathbf{C}\right)\end{array}$ & $\begin{array}{c}\text { TA } \\
\left({ }^{\circ} \mathbf{C}\right)\end{array}$ \\
\hline UBC 834 & AGA GAG AGA GAG AGA GYT & 51.6 & 46.6 \\
UBC 835 & AGA GAG AGA GAG AGA GYC & 53.9 & 48.9 \\
UBC 843 & CTC TCT CTC TCT CTC TRA & 51.6 & 46.6 \\
UBC 848 & CAC ACA CAC ACA CAC ARG & 53.9 & 48.9 \\
UBC 855 & ACA CAC ACA CAC ACA CYT & 51.6 & 46.6 \\
\hline
\end{tabular}

\section{Data analysis}

Clustering analysis of morphological character was performed using the unweighted pair group method with arithmetic mean (UPGMA) algorithm and Bray-Curtis coefficient similarity (Bray and Curtis (1957). Genome clustering of molecular character was also detected using the clustering method. Furthermore, evaluation of the appearance of a new band was also performed to know the band that belongs to banana cultivars. All of the amplification products that well defined and consistently reproducible were scored for the analysis. The ISSR band was scored 1 for present and 0 for absent. Genome clustering was analyzed based on the clustering method using the unweighted pair group method with arithmetic mean (UPGMA) algorithm and Jaccard coefficient similarity. The analysis was performed using the Paleontological Statistics (PAST) software (Hammer, 2001).

The discriminatory power of primer was evaluated by using Polymorphism information content (PIC), effective multiplex ratio (EMR), and marker index (MI) (Probojati et al. 2019). PIC was calculated with the following formula 1 :

$$
\text { PICi }=2 f i(1-f i)
$$

Where; PICi is the polymorphism information content of the primer $i$, fi is the frequency of primer fragment that was present and 1-fi is the frequency of primer fragment that was absent. EMR was determined by using formula 2:

$$
\mathrm{EMR}=\eta \cdot \beta
$$

Where; $\eta$ is the total number of fragments per primer and $\beta$ is the fraction of polymorphic fragments. MI was calculated with formula 3 proposed by Varshney et al. (2007):

$$
\mathrm{MI}=\mathrm{PIC} \times \mathrm{EMR}
$$

Where; $\mathrm{Pi}$ is frequency if the genetic type of the $\mathrm{i}$. The criterion of genetic diversity level refers to Nei (Nei 1987) where the value of genetic diversity ranges from 0.1 to 0.4 is categorized as low, while the value of $0.5-0.7$ is categorized as moderate, and value of $0.8-1.0$ is categorized as high.

\section{RESULTS AND DISCUSSION}

\section{The morphological character of banana cultivars}

Total of 33 morphological characters of banana cultivar was recorded. Bananas cultivars with genome group AA,
$\mathrm{AAA}, \mathrm{AAB}, \mathrm{ABB}$, and $\mathrm{BB}$ shared the similar characteristic including normal dwarfism (leaves not overlapped and leaf ratio superior to 2.5), the color of upper leaf surface (greenyellow until medium green) and symmetric of the insertion point of leaf blades on the petiole. The high discrimination descriptor that successfully recorded in this research is bract curling and color and petiole canal. Banana cultivars with genome group $\mathrm{AA}, \mathrm{AAA}$, and $\mathrm{AAB}$ have bract curling reflex, and rollback, whereas genome group $\mathrm{ABB}$ has bracts lift but do not roll (Figure 1). Unfortunately, we can't record banana cultivar bract with genome group BB since no bananas were found in the generative stage. Another discrimination descriptor of bract is bract color. Banana cultivars with genome group $\mathrm{AA}, \mathrm{AAA}$, and $\mathrm{AAB}$ have Red, dull purple, or yellow outside of bract, whereas genome group ABB brownish-purple of bract (Figure 1).

Typology of bract scar was also a distinctive character among genome group of the banana cultivar. Banana cultivars derived from M. acuminata have prominent bract scar while banana cultivars derived from M. balbisiana have scarcely prominent bract scar (Figure 2). Unfortunately, we can't record banana cultivar with genome group BB for comparison since no banana cultivar found in generative stage.

Petiole canal was also one of discrimination characters. Banana cultivar derived from M. acuminata tend to have petiole margin erect or spreading, with wings below and not clasping pseudostem while Banana cultivar derived from $M$. balbisiana have inclosed petiole margin, not winged below and clasping pseudostem (Figure 2). Petiole canal of banana cultivars with genome group AA and AAA in this study was similar to the characteristic of wild $M$. Acuminata (Hapsari and Masrum 2011).

\section{Cluster analysis using morphological characters}

Cluster analysis from 33 morphological data generated dendrogram separated banana cultivars into five distinct clusters based on their genome group (Figure 4). The first cluster contains banana cultivars with genome group BB (Klutuk Ijo and Klutuk Wulung). The second cluster is composed of all banana cultivars with genome group AAA and AA where Berlin (AA) is included (Figure 3). The third cluster consists of banana cultivars with genome group ABB. The fourth cluster is a banana cultivar with genome group $\mathrm{AAB}$ whereas banana cultivars with genome group AA are the last cluster (Figure 4).

Evaluation and identification of banana cultivars are necessary since Indonesia has a diversity of both wild and cultivated banana. However, various tribes and dialects have been added more confusion to proper identification and documentation not only in Indonesia but also in other countries with a high diversity of banana (Atom et al. 2015). Cultivar names are given by local community sometimes have reflected distinct morphological characteristics like smell and taste and ease us to differentiate specific banana among banana cultivars (Hapsari et al. 2017). However, various tribes and dialects have generated different names in the same banana cultivars. 


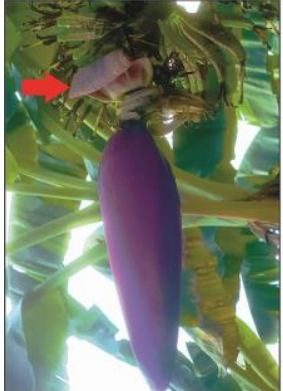

Rejang (AA)

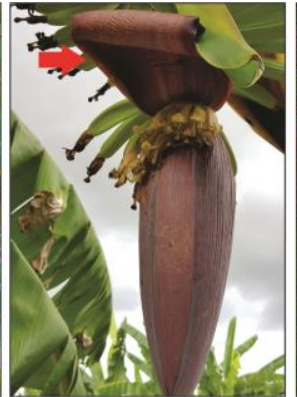

Kojo Santen (AAA) Raja Seribu (AAB)

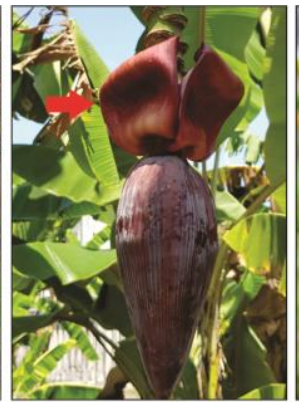

Triolin (AAB)

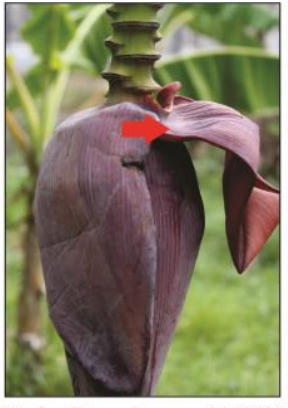

Raja Bandung (ABB) Saba Awu (ABB)

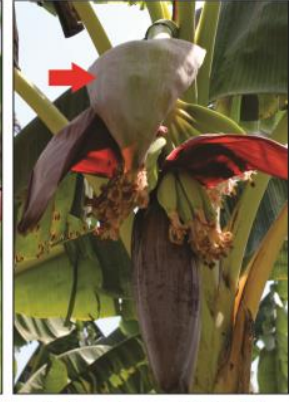

Figure 1. Bract character of banana cultivars with different genomic group

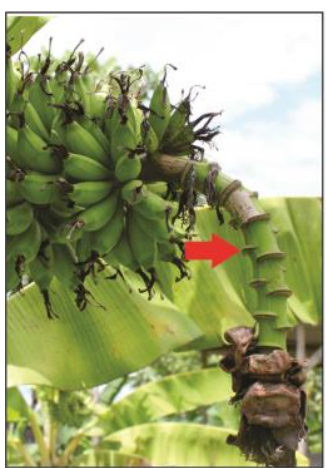

Mas (AA)

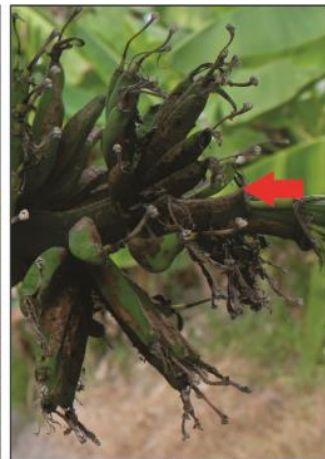

Rejang (AA)

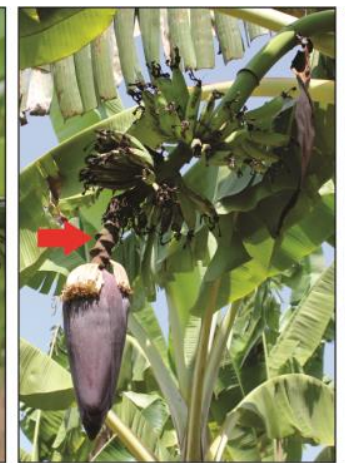

Ambon Hong (AAA)

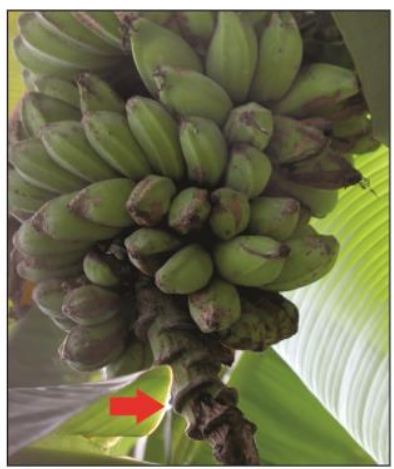

Brentel Warangan (AAB)

Figure 2. Bract scar and fruit of banana cultivars with different genome group

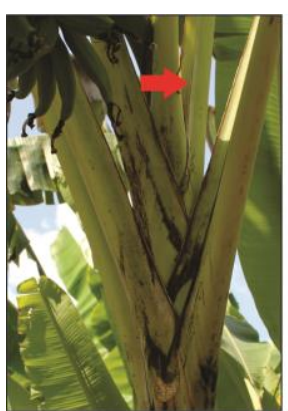

Rejang (AA)

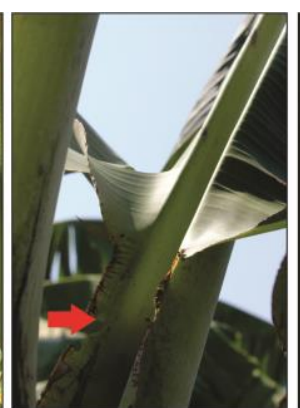

Moro Sebo (AAA) Brentel Warangan (AAB)

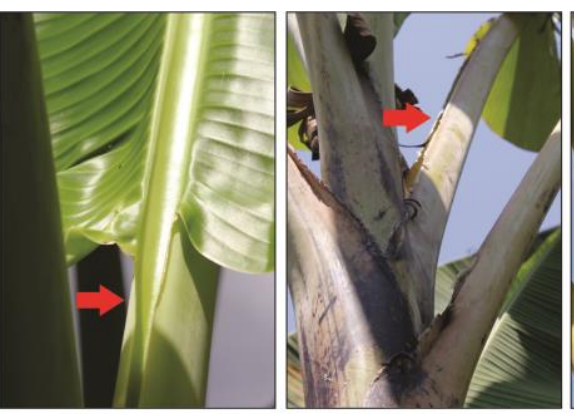

Triolin (AAB)

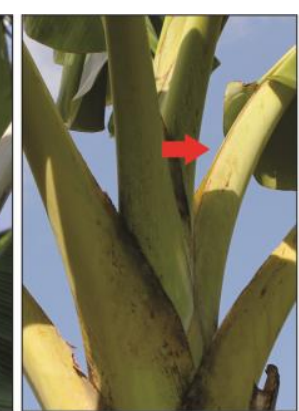

Ebung (ABB)

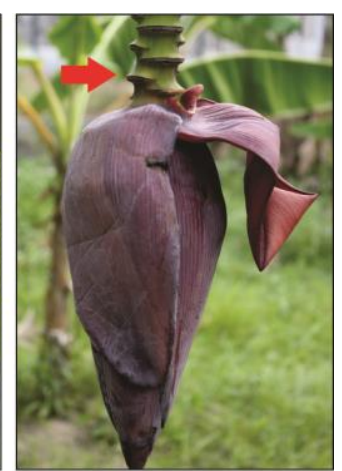

Raja Bandung (ABB)

Figure 3. Petiole canal of banana cultivars with different genome group

Scorecard by using 15 morphological characters designed by Simmond and Shepeerd (1955) have given us the breakthrough to identify banana cultivar quickly. Nevertheless, since we aren't always finding the banana cultivar in the generative stage, use the overall characteristic proposed by IPGRI was needed. A proper germplasm evaluation based on morphological character, determination and identification of relationship intra and interspecies is not only necessary for a breeding program but also as sustainability utilization of banana cultivars (Atom et al. 2014).

Determination of genome composition of a banana cultivar by using scorecard of Simmond and Shepeerd
(1955) is still relevant compared with the result of this study. Only Berlin (AA) should be evaluated since it belongs to AAA group. The subjectivity of the researcher may be the reason why Berlin belongs to the AAA group. A similar result was also obtained by Probojati et al. (2019) where the genome group produced from the morphological analysis was different from the previous study. However, generally, Banana cultivars examined in this study were grouping based on their hypothetical genetic homologies where banana cultivars with genome group $\mathrm{AA}$ and $\mathrm{BB}$ as an ancestor of the triploid banana cultivar (Valmayor et al. 2000). 


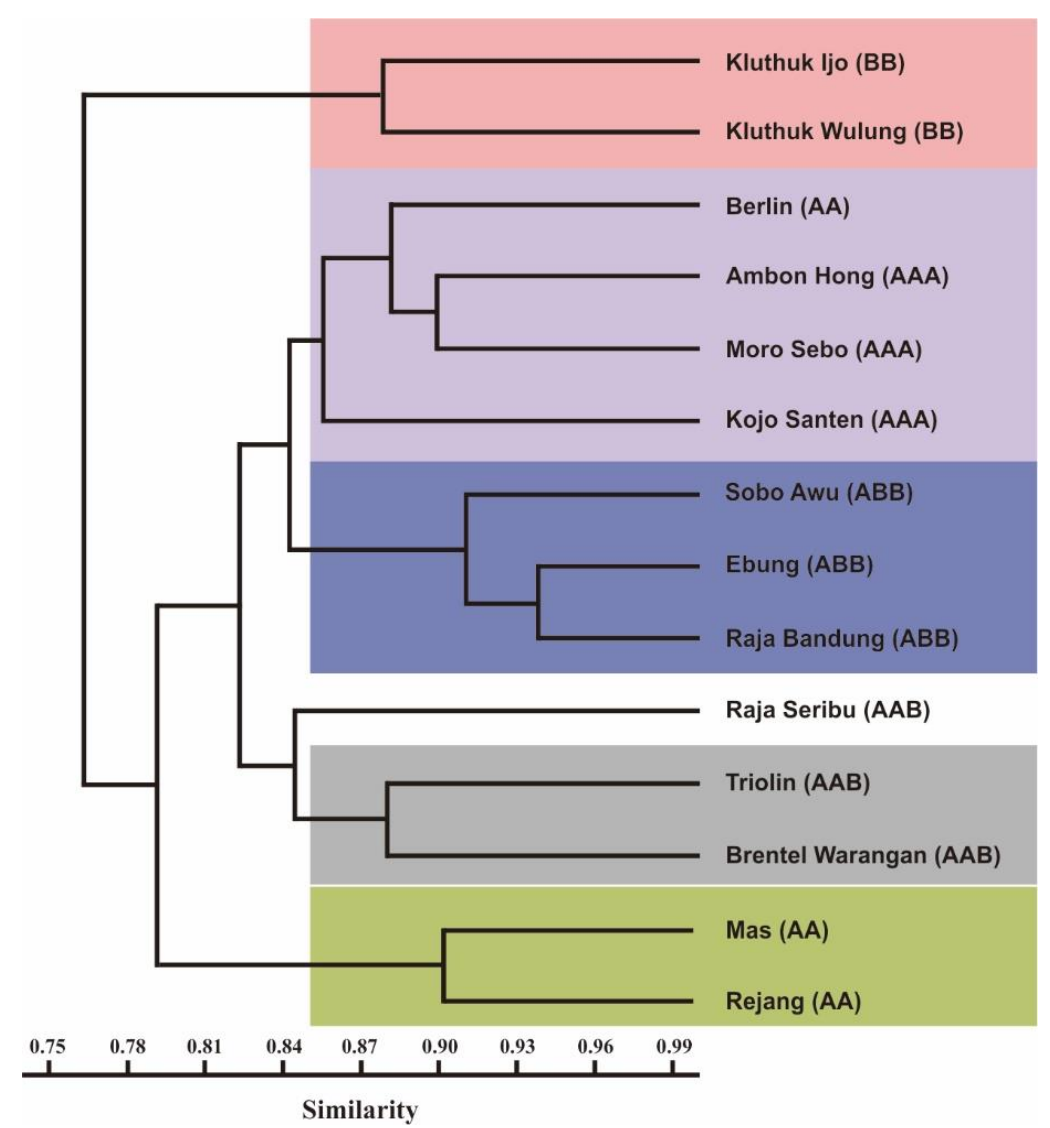

Figure 4. Dendrogram of 14 banana cultivars with difference genome group based on index similarity of Bray-Curtis

A different characteristic of diploid level (AA and $\mathrm{BB}$ ) and triploid (AAA, AAB, and $\mathrm{ABB}$ ) was also observed in anatomical character. The longer guard cells in triploid than diploid and the absence of the row of vascular bundle in $\mathrm{BB}$ and $\mathrm{ABB}$ genome was the important character in banana cultivars (Sumardi and Wulandari 2010). Furthermore, fruit nutrition content was also different in banana cultivars with different genome group. Pisang Raja Bandung and Pisang Kepok as cooking banana (ABB) have higher total sugar and carbohydrate than dessert banana (AA and AAA) (Hapsari and Lestari 2016).

\section{ISSR profile}

Total of 5 ISSR primers produced strong and weak band. Only strong bands were considered for analysis. A total of 47 ISSR band ranging from 250-1375 bp were obtained 38 bands $(80.84 \%)$ were polymorphic. The highest number band generated by UBC-855, while the lowest was UBC-834 (Table 2). The highest polymorphic band was obtained by UBC- 855 and UBC- 843 whereas the lowest was UBC-834 and UBC-835. Among selected primers, UBC-843 is the best primer because it produces the highest PIC, MI, and RP value (Table 2). However, the best primer based on their PIC, MI and RP do not guarantee it can differentiate genome group of banana cultivar. Manual analysis by checking the quality of the band and present of unique bands followed by sequencing of the specific band may solve the case.
All ISSR primers used in this study successfully generated polymorphism in the banana cultivar. All primers also successfully produced more polymorphism band than those of Poerba and Ahmad (2010) (80.82\%), Das et al. (2018) (53.83\%), and Babu et al. (2018) (58.3\%). The polymorphism may be caused by mutation at priming sites or insertion/deletion within the SSR region (Poerba and Ahmad 2010). Mutation within individual genotype produced by diverse sequences in one or two primer binding sites generated present or absence band (Poerba et al. 2018).

Different ploidy, diploid AA and $\mathrm{BB}$ and triploid AAA, $\mathrm{AAB}$ and $\mathrm{ABB}$, used in this study could be the possible reason why the polymorphism is high. Of course, environmental factors and distinct geographical conditions also play a pivotal role in genetic variation between and within species (Padmes et al. 2012). Furthermore, the polymorphism can't be separated from the capability of ISSR for assessing genetic diversity in banana cultivars.

ISSR is the best marker for assessing genetic variation, especially in banana cultivar, because of ISSR is a dominant marker and cost-effective method (Poerba et al. 2018). The use of dominant marker for assessing the genetic variation and identification of banana cultivars both intraspecies and enter species is promising since polymorphic loci could be produced in a short time without previous genome sequence information (Kiran et al. 2015). Furthermore, ISSR was showed to be more useful to differentiate genome group of banana cultivars than RAPD 
(Poerba and Ahmad 2010).

Bands indicated the character of banana cultivars were observed in UBC-855 at $500 \mathrm{bp}$ (Figure 5) because of all banana cultivar have this band. The appearance of bands showed the characteristic of genome "A" was also observed in UBC-848 at 600bp since that band appear in "A" genome and disappear in BB genome (Figure 4). Appear and disappear of the band as characteristic of "A" genome and "B" genome was also observed in RFLP (Hapsari et al. 2015). The appearance of the band may be related to the mutation and deletion (Dhakshanamoorthy et al. 2014).

The presence of unique bands along with "B" genome was also observed in UBC-834 (350 bp) and UBC-835 (300bp) (Figure 6). The sequencing of this band in the latter study was needed for recognizing what gene representing this band. The development of ISSR-SCAR markers might solve this problem. The SCAR markers were proved to be reliable and efficient for distinguishing the genus Gladiolus and its cultivars from other taxa of the family Iridaceae. Moreover, this technique is cost-effective and offers rapid identification of cultivars (Singh et al. 2017).

\section{Cluster analysis using ISSR marker}

Cluster analysis based on ISSR markers and morphological character was relatively similar. Based on minimal similarity $\geq 0,65$, banana cultivars were clustered according to their genome (Figure 7) with similarity coefficient ranged from 0,41 - 0,97 (Table 3). Only Triolin (AAB) and Raja Seribu (AAB) didn't cluster with their group. The highest similarity coefficient was obtained by Pisang Klutuk Wulung (BB) and Klutuk Ijo (BB) while the lowest was acquired by Mas (AA) and Brentel Warangan (AAB).

Genomic group of Triolin (AAB) and Raja Seribu (AAB) must be evaluated since they belong to AAA group. However, since similarity value between Raja Seribu $(\mathrm{AAB})$ and Brentel Warangan (AAB) (0.58 (Table 3) is higher than between Raja Seribu (AAB) and Morosebo (AAA) (0.49 and Raja Seribu (AAB) and Kojo Santen (AAA) (table 3), it can be concluded that Raja Seribu (AAB) belongs to AAB group. Only Pisang Triolin (AAB) and Raja Seribu (AAB) must be truly evaluated what it belongs to AAA group. The possible explanation is the dominant A genome contained in Triolin (AAB) that makes them belong to AAA group. The similar morphological performance between AA/AAA and AAB (Hapsari et al. 2015) may also contribute to why Pisang Triolon (AAB) Raja Seribu (AAB) belong to AAA group.

Table 2. Polymorphism analysis of banana cultivars by using ISSR (Inter-Simple Sequence Repeat)

\begin{tabular}{|c|c|c|c|c|c|c|}
\hline Primer & TNB & NPB & PB (\%) & PIC & EMR & MI \\
\hline UBC-834 & 7 & 6 & 85.7 & 0.49 & 42 & 20.69 \\
\hline UBC-835 & 9 & 6 & 66.7 & 0.37 & 54 & 20.03 \\
\hline UBC-843 & 10 & 9 & 90.0 & 0.50 & 90 & 44.77 \\
\hline UBC-848 & 10 & 8 & 80.0 & 0.34 & 80 & 26.84 \\
\hline UBC-855 & 11 & 9 & 81.8 & 0.48 & 99 & 47.62 \\
\hline Average & 9.4 & 7.6 & 80.84 & 0.43 & 73 & 31.9 \\
\hline
\end{tabular}
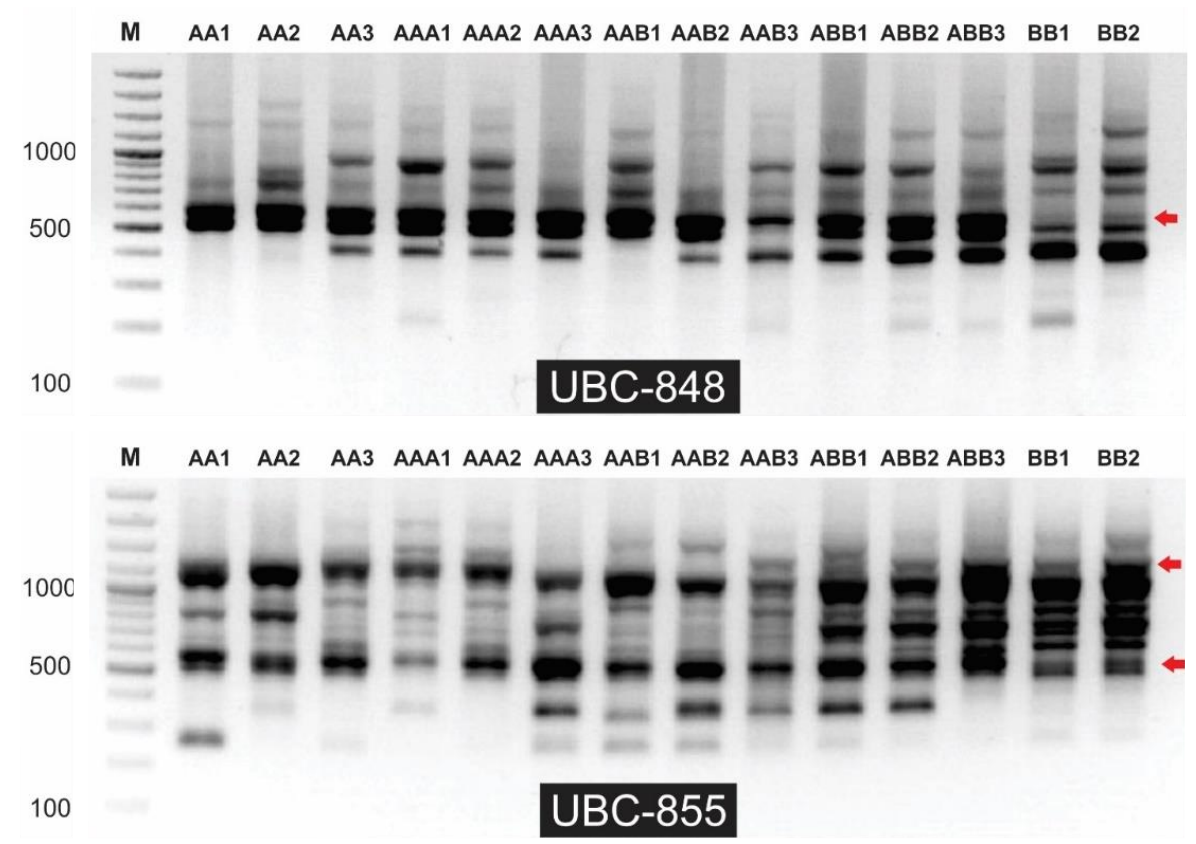

Figure 5. ISSR profile of banana cultivars that indicated the character of A (UBC-848) genome and banana cultivars (UBC-855). Note: AA1 (Pisang Rejang), AA2 (Pisang Mas), AA3 (Pisang Berlin), AAA1 (Pisang Kojo Santen), AAA2 (Pisang Ambon Hong), AAA3 (Pisang Morosebo), AAB1 (Pisang Raja Seribu), AAB2 (Pisang Triolin), AAB3 (Pisang Brentel Warangan), ABB1 (Pisang Sobo Awu), ABB2 (Pisang Ebung), ABB3 (Pisang Raja Bandung), BB1 (Pisang Kluthuk Ijo), BB2 (Pisang Kluthuk Wulung). 


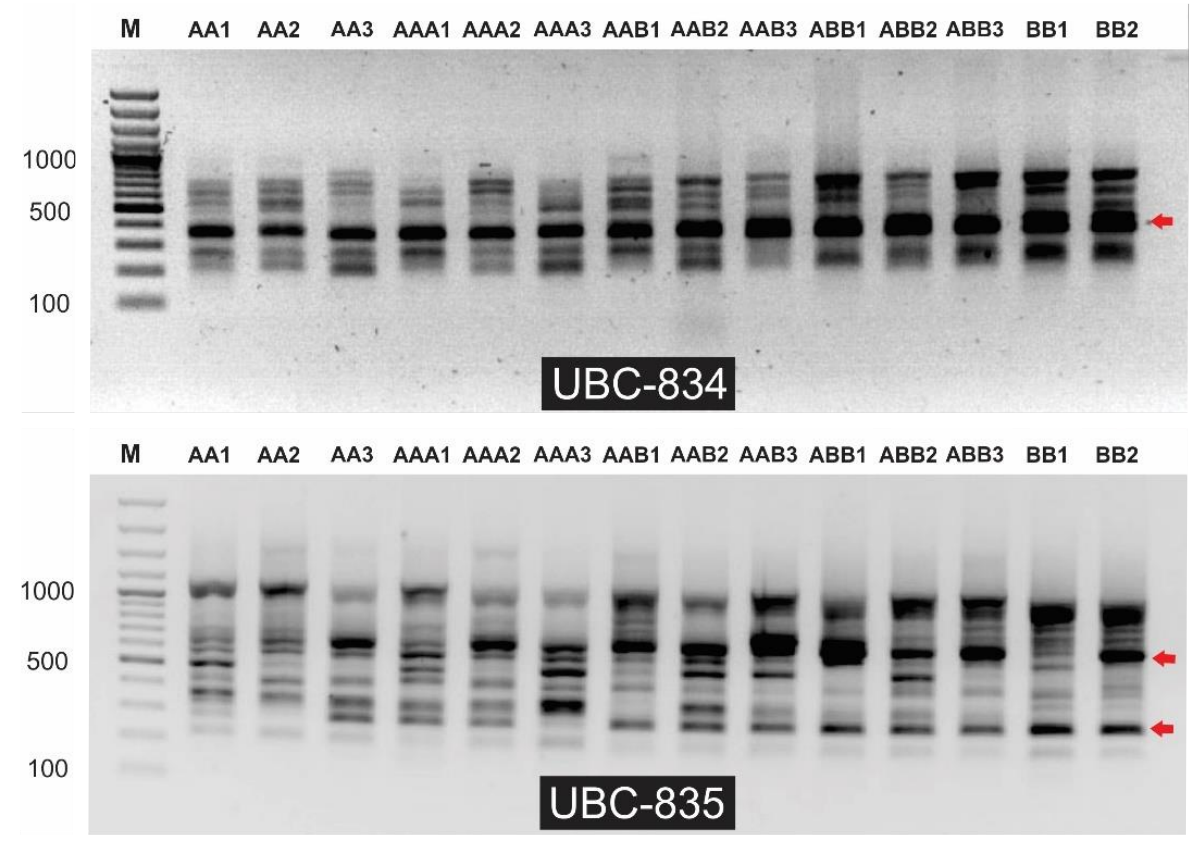

Figure 6. thickening of band indicated the characteristic of "B" genome (UBC-834) and UBC-835). Note: AA1 (Pisang Rejang), AA2 (Pisang Mas), AA3 (Pisang Berlin), AAA1 (Pisang Kojo Santen), AAA2 (Pisang Ambon Hong), AAA3 (Pisang Morosebo), AAB1 (Pisang Raja Seribu), AAB2 (Pisang Triolin), AAB3 (Pisang Brentel Warangan), ABB1 (Pisang Sobo Awu), ABB2 (Pisang Ebung), ABB3 (Pisang Raja Bandung), BB1 (Pisang Kluthuk Ijo), BB2 (Pisang Kluthuk Wulung)

Table 3. Genetic similarity between banana cultivars at different genomic groups

\begin{tabular}{|c|c|c|c|c|c|c|c|c|c|c|c|c|c|c|}
\hline & AA1 & AA2 & AA3 & AAA1 & AAA $\mathbf{A} 2$ & AAA3 & AAB1 & AAB2 & AAB3 & ABB1 & ABB2 & ABB3 & BB1 & BB2 \\
\hline AA1 & 1 & & & & & & & & & & & & & \\
\hline AA2 & 0.83 & 1 & & & & & & & & & & & & \\
\hline AA3 & 0.75 & 0.68 & 1 & & & & & & & & & & & \\
\hline AAA1 & 0.63 & 0.66 & 0.63 & 1 & & & & & & & & & & \\
\hline AAA2 & 0.54 & 0.57 & 0.57 & 0.63 & 1 & & & & & & & & & \\
\hline AAA3 & 0.61 & 0.54 & 0.58 & 0.57 & 0.48 & 1 & & & & & & & & \\
\hline AAB1 & 0.54 & 0.53 & 0.49 & 0.55 & 0.56 & 0.57 & 1 & & & & & & & \\
\hline AAB2 & 0.6 & 0.58 & 0.62 & 0.6 & 0.57 & 0.84 & 0.7 & 1 & & & & & & \\
\hline AAB3 & 0.47 & 0.41 & 0.5 & 0.48 & 0.48 & 0.55 & 0.58 & 0.5 & 1 & & & & & \\
\hline ABB1 & 0.46 & 0.44 & 0.61 & 0.55 & 0.43 & 0.49 & 0.51 & 0.53 & 0.63 & 1 & & & & \\
\hline ABB2 & 0.5 & 0.48 & 0.49 & 0.55 & 0.51 & 0.53 & 0.56 & 0.48 & 0.7 & 0.66 & 1 & & & \\
\hline ABB3 & 0.5 & 0.49 & 0.56 & 0.59 & 0.47 & 0.57 & 0.59 & 0.56 & 0.48 & 0.68 & 0.7 & 1 & & \\
\hline BB1 & 0.46 & 0.48 & 0.49 & 0.59 & 0.55 & 0.45 & 0.55 & 0.45 & 0.48 & 0.55 & 0.65 & 0.72 & 1 & \\
\hline BB2 & 0.45 & 0.47 & 0.48 & 0.57 & 0.54 & 0.47 & 0.58 & 0.48 & 0.47 & 0.54 & 0.63 & 0.7 & 0.97 & 1 \\
\hline
\end{tabular}

Note: AA1 (Pisang Rejang), AA2 (Pisang Mas), AA3 (Pisang Berlin), AAA1 (Pisang Kojo Santen), AAA2 (Pisang Ambon Hong), AAA3 (Pisang Morosebo), AAB1 (Pisang Raja Seribu), AAB2 (Pisang Triolin), AAB3 (Pisang Brentel Warangan), ABB1 (Pisang Sobo Awu), ABB2 (Pisang Ebung), ABB3 (Pisang Raja Bandung), BB1 (Pisang Kluthuk Ijo), BB2 (Pisang Kluthuk Wulung)

Banana cultivars with genome group diploid AA and triploid AAA have the highest similarity among other banana cultivars (0.54-0.83) whereas the lowest was observed between AA and BB (0.45-0.49) (Table 3). The fact that M. balbisiana (BB) was originated from the drier Area in Asia and it was introduced to Indonesia (Langhe et al. 2015) could be the possible explanation why their similarity was low. Furthermore, the similarity value of banana cultivars between and within genome group was categorized low since no similarity value that reaches 0.7
(Table 2). Only diploid AA and BB were observed to have a high similarity value within genome group.

The low similarity of populations indicates the genetic diversity that might be caused by isolation that drives the evolution of a particular trait. Besides, diverse environment or geographical condition will lead to other adaptation patterns and genetic properties (Poerba et al. 2018). However, selection and vegetative propagation was also a crucial factor in why banana cultivars have high diversity. 


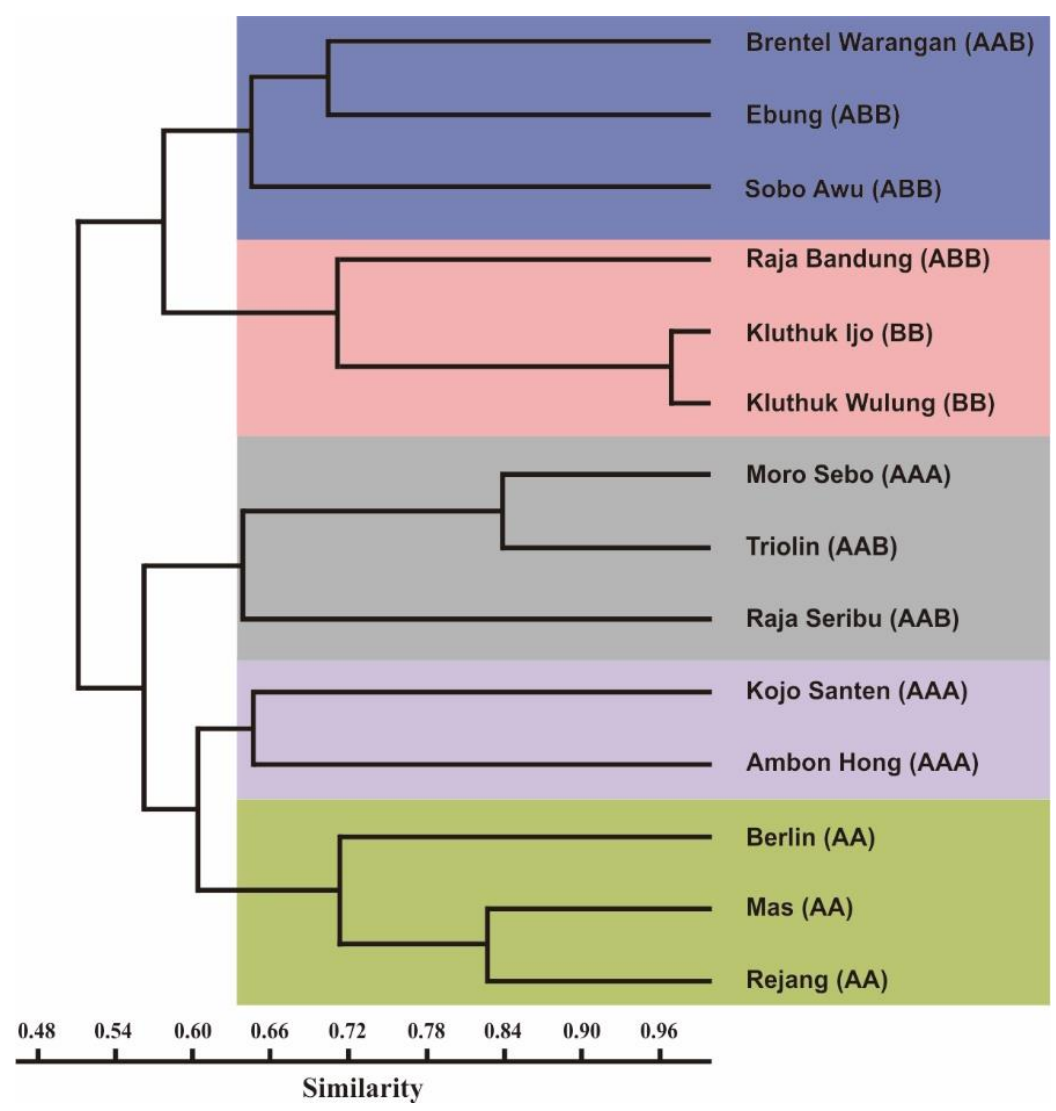

Figure 7. Dendrogram of 14 banana cultivars with difference genome group based on index similarity of Jaccard

Numerous wild species of $M$. acuminata found in Southeast Asia were widely known endemic to Southeast Asia (Atom et al., 2015) whereas M. balbisiana colla was endemic to the north-eastern region of India. M. balbisiana Colla is one ancestor of edible bananas that donate B genome (Davey et al. 2013) whereas M. acuminate donates A genome. Intra and interspecies breeding between $M$. balbisiana and M. acuminata (A genome) make up banana cultivar with different genome group including triploid hybrid ( $\mathrm{AAB}$ and $\mathrm{ABB}$ ) and tetraploid hybrid (AAAB, $\mathrm{AABB}$, and $\mathrm{ABBB}$ ) (Valmayor et al. 2000). B genome corresponds to abiotic stress or drought-tolerant (Vanhove et al. 2012) since it was mostly found in the drier area of Asia (Valmayor et al. 2000) and has demonstrated resistance to Xanthomonas (Kumakech et al. 2013).

The determination of a genomic group of banana cultivar was not only beneficial in the classification of banana but also had a crucial rule in the banana breeding program. The present study will also be in support of Poerba et al. (2018) and Hapsari et al. (2015) that genetic studies and determination of genome composition could effectively contribute the breeders in understanding the genetic resource of the plant. The identification of cultivars and classification of their genome groups based on morphological characteristics and proved by molecular markers will strengthen the establishment of Musa improvement strategy especially in Indonesia and ease the breeder to identify desirable traits of progenitor to be included in a breeding program (Gaad et al. 2018).

In conclusion, ISSR was a reliable marker to detect genome group of banana cultivars in Southeast Asia. In addition, morphological markers are also suitable for initial screening of genome group. Assessment of genome grouping of banana cultivars by using molecular markers and the morphological marker will be useful in the banana breeding program.

\section{ACKNOWLEDGEMENTS}

We appreciate for "banana team" (Farah Nadia Noor and Lailatus Sholichah) who help in the sample collection and laboratory analysis.

\section{REFERENCES}

Ahmad F, Megia R, Poerba YS. 2014. Genetic diversity of Musa balbisiana Colla in Indonesia based on AFLP marker. Hayati J Biosci 21 (1): 39-47.

Atom, Devi A, Lalrinfela P, Robert Thangjam. 2015. Genome classification of banana genetic resources of Manipur using morphological characters. Sci Vis 15 (4), 189-195.

Babu AG, Prabhuling G, Rashmi S Karani, Satish D, Patil RK, Mulla SR, Raghavendra G, Jagadeesha RC. 2018. Genetic diversity analysis among banana cultivars through ISSR markers. J Pharmacog Phytochem 7 (6): 1576-1580. 
Bray JR, Curtis JT. 1957. An ordination of the upland forest communities of Southern Wisconsin. Ecol Monogr 27: 325-349.

Das, Chandra S, Balamohan TN, Poornima K, Bergh IVD. 2018 Evaluation of Genetic Diversity in Some Banana Hybrids using ISSR Markers. Intl J Curr Microbiol App Sci 7 (1): 146-157.

Davey MW, Gudimella R, Harikrishna JA, Sin LW, Khalid N, Keulemans J. 2013. A draft Musa balbisiana genome sequence for molecular genetics in ploidy, inter- and intraspecific Musa hybrids. BMC Genomics 14: 683.

Dhakshanamoorthy D, Selvaraj R, Chidambaramb A. 2014. Utility of RAPD marker for genetic diversity analysis in gamma-rays and ethyl methane sulphonate (EMS)-treated Jatropha curcas plants. CR Biol 338, 75-82.

Gaad D, Laouar M, Gaboun F, Abdelguerfi A. 2018. Collection and agro morphological characterization of Algerian accessions of lentil (Lens culinaris). Biodiversitas 19 (1): 183-193.

Garcia SAL, Talebi R, Ferreira CF, Vroh BI, Paiva LV, Kema GHJ, Souza MT. 2011. Identification and validation of est-derived molecular markers, TRAP and VNTRS, for banana research. Acta Hort 897: 6980.

Gusmiati LH, Hapsari L, Wahyudi D. 2018. Morphological diversity and clustering of 10 cooking bananas (Musa cv. Group ABB) collection of Purwodadi Botanic Garden - LIPI. Floribunda 5 (8): 299-314. [Indonesian]

Hapsari L, Kennedy J, Lestari DA, Masrum A, Lestarini W. 2017. Ethnobotanical survey of bananas (Musaceae) in six districts of East Java, Indonesia. Biodiversitas. 18 (1), 160-174.

Hapsari L, Lestari DA. 2016. Fruit characteristic and nutrient values of four Indonesian banana cultivars (Musa spp.) at different genomic groups. J Sci 38 (3): 303-311.

Hapsari L, Wahyudi D, Azrianingsih R, Arumingtyas EL. 2015. Genome identification of bananas (Musa spp.) from East Java assessed with PCR-RFLP of the Internal Transcribed Spacer ribosomal DNA. Intl J Biosci 7 (3): 42-52.

Hapsari L. 2014. Wild Musa species collection of Purwodadi Botanic Garden: inventory and its morpho-taxonomic review. J Trop Life Sci 4 (1): 70-80. [Indonesian]

International Plant Genetic Resources Institute (IPGRI). 1996. Descriptor for Banana (Musa spp). Montpellier, Perancis.

Kharadi, Ankit, Chaudhary S, Pandey M, Chaudhary A, Sharma MC, Chikara SK. 2014. Analysis of genetic diversity amongst banana cultivars prevalent in Gujarat region of India using ISSR markers. Indian J Biotech Pharm Res 2 (2): 14-20.

Kiran U, Moahnty SK, Roy PS., Behera L, Chand PK. 2015. Genetic diversity among banana cultivars from Odisha using RAPD markers. Sci Res Rep 5 (2): 118-124.

Kumakech A, Kiggundu A, Okori P. 2013. Reaction of Musa balbisiana to banana bacterial wilt infection. Afr Crop Sci J 21: 337-346.

Langhe ED, Perrier X, Donohue M, Denham T. 2015. The Original Banana Split: Multi-disciplinary implications of the generation of African and Pacific Plantains in Island Southeast Asia. Ethnobot Res Appl 14: 299-312

Nikmah IA, Azrianingsih R, Wahyudi D. 2016. Genetic diversity of porang populations (Amorphophallus muelleri Blume) in Central Java and West Java based on LEAFY second intron marker. J Trop Life Sci 6: 23-27. [Indonesian]
Padmesh P, S. Mukunthakumar S,. Vineesh PS, Skaria R, Kumar KH, Krishnan PN. 2012. Exploring wild genetic resources of Musa acuminata Colla distributed in the humid forests of southern Western Ghats of peninsular India using ISSR markers. Plant Cell Rep 31: 1591-1601.

Perrier X, Langhe ED, Donohue M, Lentfer C, Vrydaghs L, Bakry F, Carreel F, Hippolyite I, Horry J-P, Jenny C, Lebot V, Risterucci A-M, Tomekpe K, Doutrelepont H, Ball T, Manwaring J, Maret PD, Denham T. 2011. Multidisciplinary perspectives on banana (Musa spp.) domestication. Proc Natl Acad Sci USA 108 (28): 113-118.

Poerba YS, Ahmad F. 2010. Genetic variability among 18 cultivars of cooking bananas and plantains by RAPD and ISSR markers. Biodiversitas 11 (3): 118-123.

Poerba YS, Martanti D, Ahmad F. 2018. Genetic variation of wild Musa acuminata Colla from Indonesia based on RAPD and ISSR markers. Biotropia 26 (2): 1-18. [Indonesian]

Probojati RT, Wahyudi D, Hapsari L. 2019. Clustering analysis and genome inference of Pisang Raja local cultivars (Musa spp.) from Java Island by Random Amplified Polymorphic DNA (RAPD) marker. J Trop Biodiv Biotechnol 4 (2): 42 - 53. [Indonesian]

Simmonds NW, Shepherd K. 1955. The taxonomy and origins of cultivated bananas. J Linn Soc London Bot 55: 302-312.

Singh N, Ashish K. Pal, Meena B, Roy RK, Tamta S, Rana TS. 2017. Development of ISSR- and RAPD-derived SCAR markers for identification of Gladiolus germplasm. J Hortic Sci Biotech 92: 577582.

Sumardi I, Wulandari M. 2010. Anatomy and morphology character of five Indonesian banana cultivars (Musa spp.) of different ploidy level. Biodiversitas 11 (4): 167-175.

Sundari, Arumingtyas EL, Hakim L, Azrianingsih R, Wahyudi D. 2017. Genetic variability of local durian (Durio zibethinus Murr.) in Ternate Island based on RAPD markers. Plant Cell Biotechnol Mol Biol 18: 68-75.APD

Valdez-Ojeda R, James-Kay A, Ku-Cauich J, Escobedo-Gracia Medrano RM. 2014. Genetic relationships among a collection of Musa germplasm by fluorescent-labeled SRAP. Tree Genet Genomes 10 (3): 465-476.

Valmayor RV, Jamaluddin SH, Silayoni B, Kusumo S, Danh LD, Pascua OC, Espino RRC. 2000. Banana Cultivar names and synonyms in south Asia. INIBAP, Los Banos, Philippines.

Vanhove AC, Vermaelen W, Panis B, Swennen R, Carpentier SC. 2012. Screening the banana biodiversity for drought tolerance: can an in vitro growth model and proteomics be used as a tool to discover tolerant varieties and understand homeostasis. Front Plant Sci 3: 176.

Varshney RK, Chabane K, Hendre PS, Aggarwal RK, Graner A. 2007. Comparative assessment of EST-SSR, EST-SNP and AFLP markers for evaluation of genetic diversity and conservation of genetic resources using wild, cultivated and elite barleys. Plant Sci 173: 638649.

Wahyudi D, Azrianingsih R, Mastuti R. 2015. Genetic variability of porang populations (Amorphophallus muelleri) in West Java and Central Java based on trnL intron sequences. J Biodiv Environ Sci 3: 31-41.

Youssef M, James A, Rivera-Madrid R, Ortiz R, Escobedo-Gracia Medrano RM. 2011. Musa genetic diversity revealed by SRAP and AFLP. Mol Biotech 47 (3): 189-199. 